\title{
SIMULTANEOUS MEASUREMENTS OF THE BLOOD VOLUME IN MAN AND DOG BY MEANS OF EVANS BLUE DYE, T1824, AND BY MEANS OF CARBON MONOXIDE. II. UNDER ABNORMAL CONDITIONS, INCLUDING SECONDARY SHOCK ${ }^{1}$
}

\author{
By JAMES HOPPER, JR., ${ }^{2}$ ALEXANDER W. WINKLER, AND J. RUSSELL ELKINTON 3 \\ (From the Department of Internal Medicine, Yale University School of Medicine, and from the Medical \\ Service of the New Haven Hospital, New Haven)
}

(Received for publication September 20, 1943)

The results of simultaneous measurements of the volume of distribution of carbon monoxide and that of Evans blue dye (T1824), in normal man and in normal and splenectomized dogs, have been reported elsewhere (1). It was found that, although measurements of the blood volume by the 2 methods were frequently numerically equivalent, occasionally either carbon monoxide or dye might measure a larger space. On the average, the results with the 2 methods were very nearly the same, in spite of these occasional variations. In the present study, the same method of investigation has been applied to pathological subjects. Studies, both of patients and of dogs, have been carried out. The human subjects consisted of hospitalized patients with various disorders, affecting either the state of the vascular system or the chemical constitution of the body fluids. The dogs were first studied in their normal state, and again after being subjected to various procedures likely to affect the vascular system. These experimental procedures included traumatic shock, salt and water depletion, hemorrhage, adrenal insuffciency, and the injection of epinephrine. The extent to which the normal relationship existing between the results obtained by the 2 methods persisted in pathological states could thus be determined. Furthermore, in the dog experiments, the reliability of these 2 methods as relative measures of blood volume could to some extent be determined. The results could also be com-

${ }^{1}$ Aided by grants from the Fluid Research Fund, Yale University School of Medicine, from the John and Mary R. Markle Foundation, and from the Ella Sachs Plotz Fund.

2 Alexander Brown Coxe Fellow, 1941-1942, and American College of Physicians Fellow, 1942-1943.

National Research Council Fellow in the Medical Sciences, 1940-1941. pared in this respect with parallel estimations of changes in blood volume calculated from changes in concentration of serum protein and from changes in the fraction of cells in whole blood as determined by the hematocrit.

\section{METHODS}

The methods have for the most part been described elsewhere $(1,2)$. The details of the technic of simultaneous measurements with dye 4 and with carbon monoxide, of the handling of blood, of hematocrit determinations, and of the general procedure were the same as in the previous study (1). Serum protein concentrations were determined by the macro-Kjeldahl technic (3). The formulae used for calculating plasma volume changes from changes in serum protein concentration and from changes in relative cell volume are as follows:

$$
\frac{\mathrm{PV}_{2}}{\mathrm{PV}_{1}}=\frac{\mathrm{SP}_{1}}{\mathrm{SP}_{2}}
$$

and

$$
\frac{P V_{2}}{P V_{1}}=\frac{\left(1-H k t_{2}\right)\left(H k t_{1}\right)}{\left(1-H k t_{1}\right)\left(H k t_{2}\right)}
$$

where $P V_{1}=$ initial plasma volume

$\mathrm{PV}_{2}=$ subsequent plasma volume

$\mathrm{SP}_{1}=$ initial serum protein

$\mathrm{SP}_{2}=$ subsequent serum protein

$\mathrm{Hkt}_{1}=$ initial fraction of cells in whole blood

$\mathrm{Hkt}_{2}=$ subsequent fraction of cells in whole blood

\section{Procedue in shock due to ligature}

In the shock experiments, a preliminary blood volume study was done with or without the use of "Dial" anesthesia $(0.6 \mathrm{cc}$. per $\mathrm{kgm}$. body weight). Frequently, additional control blood volume studies were done, including one under anesthesia just before the induction of shock, with a tracheal cannula in place for the administration of carbon monoxide. To produce shock, a hind leg was tightly ligated with rubber tubing. The following morning, 8 to 12 hours later, the rubber tubing was removed. Two to

Blue dye T-1824 furnished by the Warner Institute of Therapeutic Research, New York. 
3 hours after removal of the tourniquet, when the hind extremity had become edematous and when signs of shock were well developed, the blood volume was again determined. Subsequent blood volume and blood chemical determinations were done in some experiments (Table II). At death, the 2 hind legs were removed and the difference in weight between the edematous and the normal limb determined.

"Dial" anesthesia has a marked effect upon the spleen and upon the distribution of red cells in the circulation $(4,5)$. Since, however, "Dial" was administered before the control period and its action persisted during subsequent periods, these effects were present at all times, and hence could not have been responsible for the observed changes in blood volume. This conclusion was confirmed in certain experiments in which splenectomized animals under "Dial" anesthesia were used for shock studies. These animals behaved as did other shocked animals with respect to blood volume changes.

\section{Procedure in salt and water depletion experiments}

Control studies followed by studies under various conditions of depletion were made as indicated in Table III. One dog (22B), dehydrated by deprivation of water and food, was also depleted of salt by the withdrawal of peritoneal fluid some hours after the intraperitoneal injection of a 5 per cent glucose solution (6). In one normal dog (26A), peritoneal fluid was withdrawn a few hours after the injection of 10 per cent urea dissolved in the 5 per cent glucose solution. This resulted eventually in a large depletion of water, as well as of salt, since the absorbed urea provoked a copious diuresis. Two dogs $(25 \mathrm{~A}, 26 \mathrm{~B})$ served as controls for this procedure. They received no urea in the $\mathbf{5}$ per cent glucose solution, so that salt depletion alone resulted. Finally, 2 dogs (25B, 29), initially dehydrated by prolonged withdrawal of food and water, subsequently received repeated intraperitoneal injections of a 5 per cent sodium chloride solution. Certain data from these last 2 experiments have been published elsewhere (11).

\section{Procedure for studies after adrenalectomy}

The dog used in this study had been adrenalectomized 2 weeks previous to the time experiments were begun and in the interval had been adequately maintained on salt, cortin, and desoxycorticosterone. Simultaneous measurements were then made both when the animal was adequately maintained on drug therapy, and again after withdrawal of therapy, as indicated in Table IV. In these experiments, as in the hemorrhage experiments, residual carbon monoxide in the lung-bag system was not determined, a constant correction factor being used. Similarly, the mask for administering carbon monoxide was not sealed with petrolatum. Sulfocyanate space was measured by the method of Elkinton and Taffel (7).

\section{Procedure in hemorrhage experiments}

A single animal was used. Several control blood volumes were first done. The animal was then bled 200 to
$400 \mathrm{cc}$. daily on 2 or 3 successive days. After an interval of 24 to 72 hours following the last hemorrhage, another blood volume study with both methods was made. Between blood volume studies, the animal was well fed. The usual 12- to 18-hour fast, however, preceded all blood volume measurements. In these studies, residual carbon monoxide in the lung-bag space was not determined. Instead, an arbitrary constant correction was made. Also, in these studies, the mask for administering carbon monoxide was not sealed around the dog's muzzle with petrolatum. Failure to observe this precaution may have resulted in loss of carbon monoxide from the mask in certain of the studies.

\section{Procedure in experiments in which epinephrine was used}

To study the vascular effects of epinephrine upon simultaneous carbon monoxide and dye measurements, control blood volume studies were done in the usual way. Immediately after taking the final blood samples for the control study, and with the mask in place so that the animal remained in equilibrium with the carbon monoxide, $1 \mathrm{cc}$. of 1:1000 epinephrine was given rapidly intravenously. No further injection of dye was made. During the following $2 \frac{1}{2}$ to 10 minutes, 1 or 2 blood samples were taken for the simultaneous measurement of carbon monoxide and of dye concentrations and for hematocrit and serum protein studies. Dye measurements are omitted since it was not possible to distinguish quantitatively between the effects on concentration of dye in serum of continuing dye loss and those due to alterations in plasma volume induced by epinephrine.

\section{RESULTS}

\section{In patients with various clinical conditions}

In Table $I$ are presented the results of 22 studies in 11 patients in whom measurements were made simultaneously with carbon monoxide and T1824. These hospitalized subjects suffered from various diseases, indicated in Table $I$. With such a variety of diagnoses, and with various stages and varieties of these diseases represented, mean values for the group must be interpreted even more cautiously than were those in a corresponding normal group (1). The ratios of blood volume measurements by the 2 methods are calculated in the final column of Table $I$. Only 6 of the 22 ratios fall between 0.95 and 1.05 , the range of probable equality, and only 9 between 0.90 and 1.10 , the extreme range of possible equality (1). Of the remaining 13 ratios, 12 exceed 1.10 while only 1 falls below 0.90 . The measurements by the dye method therefore exceed those by the monoxide method in more than half the cases, and give virtually the same results 
TABLE I

Simultaneous measurements of blood volume with a carbon monoxide method and with a dye (T1824) method in patients with various diseases

\begin{tabular}{|c|c|c|c|c|c|c|c|c|c|c|}
\hline \multirow{3}{*}{ Subject } & \multirow{3}{*}{ Sex } & \multirow{3}{*}{ Diagnosis } & \multirow{3}{*}{ Date } & \multirow{3}{*}{$\begin{array}{c}\text { Body } \\
\text { weight }\end{array}$} & \multirow{3}{*}{ Height } & \multirow{3}{*}{$\begin{array}{l}\text { Serum } \\
\text { protein }\end{array}$} & \multirow{3}{*}{$\begin{array}{c}\text { Relative } \\
\text { cell } \\
\text { volume }\end{array}$} & \multicolumn{2}{|c|}{ Blood volume } & \multirow{3}{*}{ Ratio 2:1 } \\
\hline & & & & & & & & 1 & 2 & \\
\hline & & & & & & & & $\begin{array}{c}\text { CO } \\
\text { method }\end{array}$ & $\begin{array}{c}\text { Dye } \\
\text { method }\end{array}$ & \\
\hline \multirow{3}{*}{ S.B. } & \multirow{3}{*}{$\mathbf{M}$} & \multirow{3}{*}{$\begin{array}{l}\text { Acute nephritis } \\
\text { ? hydronephrosis }\end{array}$} & 1942 & kgm. & $\mathrm{cm}$. & $\underset{\text { per cent }}{\text { grams }}$ & per cent & $c c$. & $c c$. & \\
\hline & & & $\begin{array}{l}\text { Apr. } 22 \\
\text { May } 27\end{array}$ & $\begin{array}{l}56.0 \\
55.0\end{array}$ & $\begin{array}{l}173 \\
173\end{array}$ & $\begin{array}{l}6.33 \\
7.46\end{array}$ & $\begin{array}{l}47.0 \\
51.0\end{array}$ & $\begin{array}{l}4380 \\
3965\end{array}$ & $\begin{array}{l}4960 \\
4490\end{array}$ & $\begin{array}{l}1.13 \\
1.13\end{array}$ \\
\hline & & & July 1 & 52.4 & 173 & 6.53 & 38.6 & 3950 & 3900 & 0.99 \\
\hline D.A. & $\mathbf{F}$ & Mercury poisoning, mild & May 13 & 55.5 & 158 & 7.47 & 36.1 & 3930 & 4730 & 1.20 \\
\hline & & & May 25 & 50.0 & 158 & 7.11 & 38.6 & 3675 & 4110 & 1.12 \\
\hline G.H. & $\mathbf{M}$ & Addison's disease treated & $\begin{array}{ll}\text { July } & 6 \\
\text { Julv } & 8\end{array}$ & 57.0 & & 5.62 & 32.2 & 5185 & 5375 & 1.04 \\
\hline & & & July 13 & 57.1 & & $\begin{array}{l}0.11 \\
5.75\end{array}$ & $\begin{array}{l}29.5 \\
28.9\end{array}$ & $\begin{array}{l}4090 \\
5930\end{array}$ & $\begin{array}{l}5118 \\
5438\end{array}$ & $\begin{array}{l}1.09 \\
0.92\end{array}$ \\
\hline S.M. & F & Addison's disease treated & Oct. 16 & 63.0 & 156 & 7.12 & 38.5 & 3900 & 3300 & 0.85 \\
\hline HS & F & Hynerthyroidism hefore and & Oct. 30 & $\begin{array}{l}63.0 \\
48.0\end{array}$ & 156 & $\begin{array}{l}5.69 \\
702\end{array}$ & $\begin{array}{l}34.2 \\
460\end{array}$ & $\begin{array}{l}3870 \\
3475\end{array}$ & $\begin{array}{l}3585 \\
3080\end{array}$ & 0.93 \\
\hline & & after operation & Apr. 29 & 48.0 & 158 & 7.32 & 32.6 & 3605 & 3450 & 0.96 \\
\hline F.C. & $\mathbf{F}$ & $\begin{array}{l}\text { Hyperthyroidism, before and } \\
\text { af ter operation }\end{array}$ & $\begin{array}{l}\text { June } 8 \\
\text { June } 25\end{array}$ & $\begin{array}{l}88.0 \\
88.0\end{array}$ & & $\begin{array}{l}6.87 \\
6.43\end{array}$ & $\begin{array}{l}49.0 \\
48.3\end{array}$ & $\begin{array}{l}5350 \\
5000\end{array}$ & $\begin{array}{l}6170 \\
6140\end{array}$ & 1.15 \\
\hline M.M. & $\mathbf{F}$ & Hyperthyroidism, before and & June 10 & 59.0 & 155 & 6.72 & 45.7 & 3330 & 3820 & 1.15 \\
\hline & & after operation & June 24 & 59.0 & 155 & 6.28 & 38.8 & 3500 & 3490 & 1.00 \\
\hline $\begin{array}{l}\text { H.R. } \\
\text { N.C. }\end{array}$ & $\begin{array}{l}\mathbf{F} \\
\mathbf{M}\end{array}$ & $\begin{array}{l}\text { Portal cirrhosis } \\
\text { Portal cirrhosis }\end{array}$ & May 20 & $\begin{array}{l}50.4 \\
69.7\end{array}$ & & $\begin{array}{l}6.42 \\
5.05\end{array}$ & $\begin{array}{l}54.3 \\
34.4\end{array}$ & $\begin{array}{l}3910 \\
6340\end{array}$ & $\begin{array}{l}5690 \\
6560\end{array}$ & 1.46 \\
\hline B.L. & $\mathbf{M}$ & Cardiac decompensation at & Apr. 15 & 62.0 & & 4.88 & $\begin{array}{l}34.4 \\
39.2\end{array}$ & $\begin{array}{l}0340 \\
5150\end{array}$ & $\begin{array}{l}0500 \\
5940\end{array}$ & $\begin{array}{l}1.04 \\
1.15\end{array}$ \\
\hline & & different stages of recovery & Apr. 27 & 54.4 & & 5.61 & 37.9 & 5245 & 5340 & 1.02 \\
\hline H.E. & M & Lymphogranuloma inguinale & Apr. 24 & $\begin{array}{l}51.0 \\
69.1\end{array}$ & & $\begin{array}{l}3.41 \\
7.98\end{array}$ & $\begin{array}{l}35.5 \\
47.9\end{array}$ & $\begin{array}{l}4800 \\
4080\end{array}$ & $\begin{array}{l}5970 \\
5780\end{array}$ & $\begin{array}{l}1.24 \\
1.42\end{array}$ \\
\hline
\end{tabular}

in most of the remaining ones. Correlation of the ratios with clinical diagnosis cannot be attempted because there are too few cases of any one type.

\section{In shock due to ligature in normal and splenecto- mized dogs}

The results of these experiments are presented in Table II. Nine dogs were used in these experiments, 5 of which were normal and 4 splenectomized. Twenty-five simultaneous determinations of the blood volume were done. As indicated by both methods, blood volume regularly decreased following the establishment of shock. In 1 instance only (experiment 1 ), the dye method remained unchanged, and even here the monoxide method recorded a decline. The magnitude of this decrease was greater by the monoxide than by the dye method in about half the experiments, and was of about the same degree in the remainder. This is indicated by the behavior of the ratios between the 2 measurements, recorded in the final column. During shock, dye T1824 frequently measures a much larger volume than does carbon monoxide, the magnitude of some of the ratios greatly exceeding those ever found in normal circumstances. The differences between the behavior of the measurements in different experiments may be related to the fact that the intensity and duration of shock varied considerably from experiment to experiment.

The decline in blood volume occurred mainly at the expense of the plasma fraction. This was to be expected from the nature of the experimental procedure, which causes a transudation of fluid containing plasma, but few erythrocytes, into the tissues of the ligated limb immediately on removal of the ligature (8). Little change in total cell volume should therefore be recorded by a reliable measurement of blood volume; a small decrease only might be expected as the result of removal of blood for analytical purposes. The total cell volumes measured by each of the 2 methods are presented in Table II. The expected result-no essential change or a slight decrease - was found in about half the experiments. In the remaining experiments, the dye method recorded an increase 3 times and a sharp 
decrease only once, while the monoxide method recorded an increase once and a striking decrease 3 times. These results suggest that, on occasion, both methods are quite unreliable, but they tend to err in opposite directions. The monoxide method sometimes may give lower than usual values for the blood volume in this type of shock, while the dye method may give values higher than usual.

\section{In dehydrated animals with and without salt de- pletion}

In Table III are presented the results in 6 experiments in which water or salt content of the body had been altered. Acute salt depletion of sufficient severity will induce cardiovascular collapse, secondary shock, and death (9). This procedure was carried out 5 times in 4 experiments (22B, 25A, 26A, 26B). The monoxide method indicated a fall in blood volume in every case in which it was carried out, while the dye method indicated a fall only 2 times out of 5 . There was, therefore, a dissociation between the results by the 2 methods in the remaining 3 instances, and the ratio between them rose. Simple water deprivation results in loss of body water from all compartments (10), and might be expected to reduce blood volume if it altered it at all. In the 3 experiments with prolonged water deprivation (22B, 25B, and 29), blood volume as measured by both methods did consistently decline.' Water deprivation combined with injection of hypertonic saline, on the other hand, tends to maintain or expand the volume of

TABLE II

Simultaneous measurements of blood volume of dogs with a carbon monoxide method and with a dye (T1824) method, before and during secondary shock, induced by release of a ligature constricting the thigh

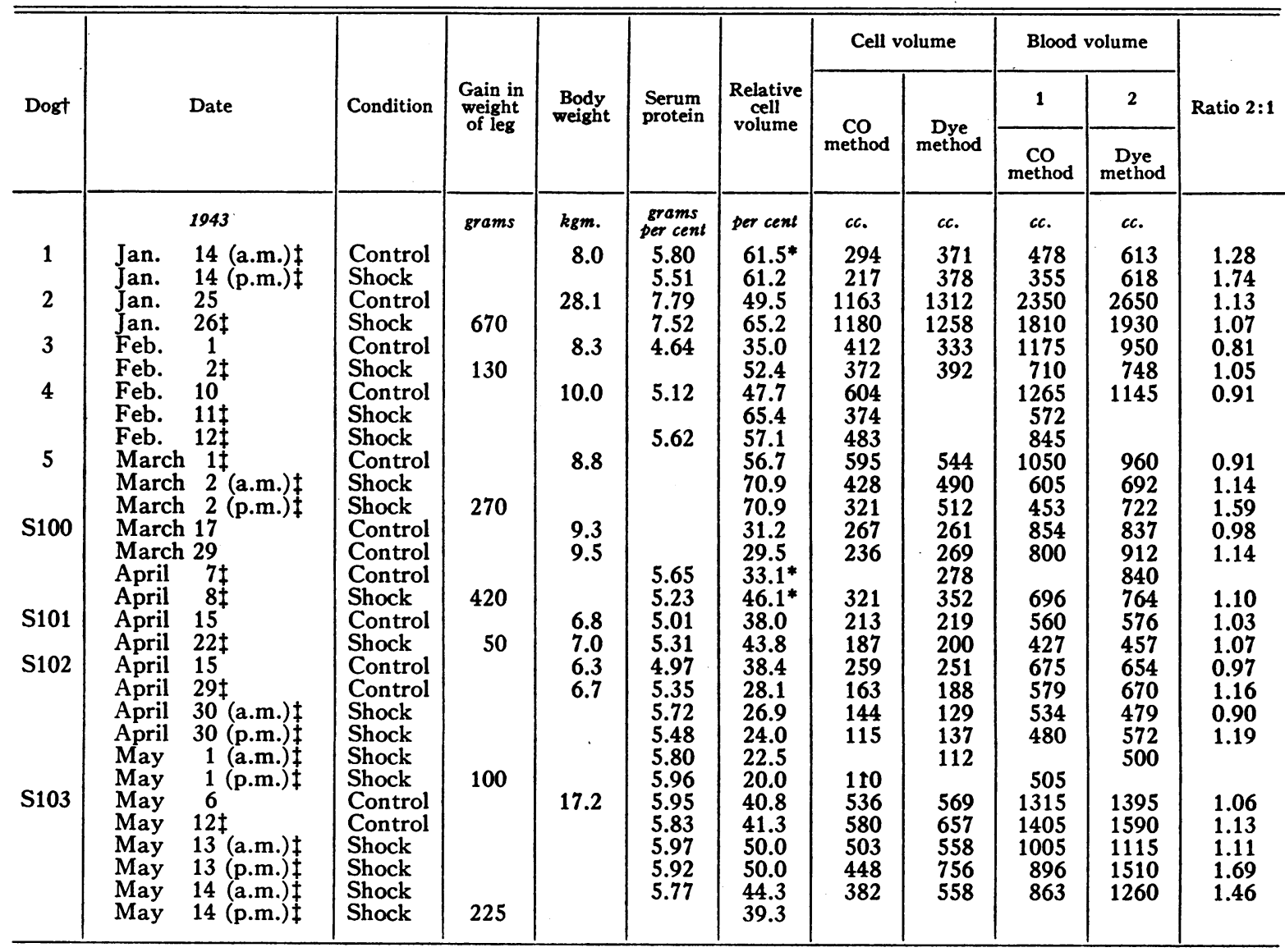

* Venous instead of arterial blood used.

† Letter "S" refers to splenectomized dogs.

$\ddagger$ Anesthetized with Dial and tracheal cannula in place. 
the extracellular fluid at the expense of the intracellular (11). Blood volume might therefore be expected to increase, at least for a time. In the 2 experiments bearing on this point (experiments $25 \mathrm{~B}$ and 29 ), the monoxide method indicated an increase in one and no change in the other. In the single experiment in which dye measurements were made, there was a moderate decrease of blood volume, not indicated by the simultaneous monoxide method.

Taking the results of these experiments all together, it appears that, in most instances, both methods tend to confirm one another, and indicate changes in the direction to be predicted on physiological grounds. The single important exception is the failure of the dye method to record any decline in blood volume in certain instances of shock due to acute salt depletion (22B, 25A), in which there is much reason to believe that some decline occurred. Because changes in plasma salt concentration such as were produced in these experiments radically affect relative cell volume without necessarily altering the blood volume, calculations of total cell mass by the 2 methods are of little value in assessing the relative soundness of the 2 methods, and so have been omitted.

\section{In the adrenalectomized animal}

Simultaneous measurements after adrenalectomy (Table IV) are characterized for the most part by failure of the 2 methods to agree, the ratios varying from 0.75 to 1.54 without evident relation to the clinical state. In the studies of May 18 and of July 16, when treatment of adrenal cortical insufficiency was definitely inadequate, as indicated by the contraction of the sulfocyanate space, both methods indicated lower

\section{TABLE III}

Simultaneous measurements of blood volume by a carbon monoxide method and by a dye (T1824) method, in dogs subjected to water and salt depletion and in dogs receiving injections of hypertonic saline

\begin{tabular}{|c|c|c|c|c|c|c|c|c|}
\hline \multirow{3}{*}{ Dost } & \multirow{3}{*}{ Date } & \multirow{3}{*}{ Procedure } & \multirow{3}{*}{$\begin{array}{c}\text { Body } \\
\text { weight }\end{array}$} & \multirow{3}{*}{$\begin{array}{l}\text { Serum } \\
\text { protein }\end{array}$} & \multirow{3}{*}{$\begin{array}{c}\text { Relative } \\
\text { cell } \\
\text { volume }\end{array}$} & \multicolumn{2}{|c|}{ Blood volume } & \multirow{3}{*}{ Ratio 2:1 } \\
\hline & & & & & & 1 & 2 & \\
\hline & & & & & & $\begin{array}{c}\text { CO } \\
\text { method }\end{array}$ & $\begin{array}{c}\text { Dye } \\
\text { method }\end{array}$ & \\
\hline \multirow[b]{2}{*}{ 22B } & 1943 & & kgm. & $\begin{array}{c}\text { grams } \\
\text { per cent }\end{array}$ & per cent & $c c$. & $c c$. & \\
\hline & $\begin{array}{ll}\text { Jan. } & 7 \text { (a.m.) } \\
\text { Jan. } & 7 \text { (p.m.) } \\
\text { Jan. } & 9 \\
\text { Jan. } & 11 \\
\text { Jan. } & 12\end{array}$ & $\begin{array}{l}\text { Normal control } \\
\text { After acute salt depletion } \\
\text { Continued water deprivation } \\
\text { Continued water deprivation } \\
\text { Continued water deprivation, fur- } \\
\text { ther salt depletion }\end{array}$ & $\begin{array}{l}14.6 \\
14.5 \\
13.2 \\
12.4 \\
12.2\end{array}$ & $\begin{array}{l}5.08^{*} \\
6.17^{*} \\
6.42^{*} \\
6.72^{*} \\
7.09^{*}\end{array}$ & $\begin{array}{l}57.1^{*} \\
61.3^{*} \\
56.8^{*} \\
59.9^{*} \\
54.6^{*}\end{array}$ & $\begin{array}{l}1590 \\
1200 \\
1390 \\
1250\end{array}$ & $\begin{array}{l}1330 \\
1405 \\
1350 \\
1150 \\
1122\end{array}$ & $\begin{array}{l}0.89 \\
1.12 \\
0.83 \\
0.90\end{array}$ \\
\hline $25 \mathrm{~A}$ & 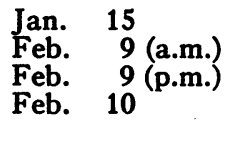 & $\begin{array}{l}\text { Continued water deprivation } \\
\text { Normal control } \\
\text { After acute salt depletion } \\
\text { Water by mouth without salt resto- } \\
\text { ration }\end{array}$ & $\begin{array}{r}11.2 \\
8.5 \\
8.4 \\
8.2\end{array}$ & $\begin{array}{l}6.57^{*} \\
6.15 \\
7.08 \\
6.03\end{array}$ & $\begin{array}{l}51.8^{*} \\
44.4 \\
49.7 \\
41.8\end{array}$ & $\begin{array}{r}1120 \\
965 \\
842 \\
792\end{array}$ & $\begin{array}{r}860 \\
979 \\
1020 \\
928\end{array}$ & $\begin{array}{l}0.77 \\
1.01 \\
1.21 \\
1.17\end{array}$ \\
\hline 25B & $\begin{array}{ll}\text { Feb. } & 24 \\
\text { March } & 4 \\
\text { March } & 6 \\
\text { March } & 8 \\
\text { Feb. } & 5 \text { (a.m.) }\end{array}$ & $\begin{array}{l}\text { Normal control } \\
\text { Water deprivation since Feb. } 24 \\
\text { Hypertonic saline; water deprivation } \\
\text { Hypertonic saline; water deprivation } \\
\text { Normal control }\end{array}$ & $\begin{array}{l}8.5 \\
7.0 \\
6.6 \\
6.3 \\
9.3\end{array}$ & $\begin{array}{l}5.86 \\
6.83 \\
6.08 \\
5.44 \\
4.59\end{array}$ & $\begin{array}{l}41.3 \\
47.4 \\
42.8 \\
31.0 \\
35.0\end{array}$ & $\begin{array}{r}890 \\
700 \\
633 \\
873 \\
+\end{array}$ & 934 & 1.05 \\
\hline 26B & $\begin{array}{l}\text { Feb. } \quad 5 \text { (p.m.) } \\
\text { Feb. } 6 \text { (a.m.) } \\
\text { Feb. } 15 \text { (a.m.) } \\
\text { Feb. } 15 \text { (p.m.) } \\
\text { Feb. } 24 \\
\text { March } 4 \\
\text { March } 6 \\
\text { March } 8 \\
\text { March } 10\end{array}$ & $\begin{array}{l}\text { After acute salt depletion } \\
\text { After salt and water depletion } \\
\text { Normal control } \\
\text { After acute salt depletion } \\
\text { Normal control } \\
\text { Water deprivation since Feb. } 24 \\
\text { Hypertonic saline; water deprivation } \\
\text { Hypertonic saline; water deprivation } \\
\text { Hypertonic saline; water deprivation }\end{array}$ & $\begin{array}{l}8.8 \\
8.0 \\
8.5 \\
8.1 \\
7.9 \\
6.5 \\
6.1 \\
5.7 \\
5.3\end{array}$ & $\begin{array}{l}5.78 \\
5.19 \\
4.74 \\
5.84 \\
5.67 \\
5.75 \\
5.43 \\
5.31 \\
5.04\end{array}$ & $\begin{array}{l}44.4 \\
32.3 \\
32.0 \\
37.5 \\
45.4 \\
46.6 \\
38.7 \\
34.8 \\
25.2\end{array}$ & $\begin{array}{l}770 \\
746 \\
950 \\
524 \\
884 \\
660 \\
685 \\
611\end{array}$ & $\begin{array}{l}746 \\
776 \\
800 \\
670 \\
828 \\
700 \\
619 \\
617 \\
538\end{array}$ & $\begin{array}{l}0.97 \\
1.04 \\
0.84 \\
1.28 \\
0.94 \\
1.06 \\
0.90 \\
1.01\end{array}$ \\
\hline
\end{tabular}

* Venous instead of arterial sample used.

† See control studies of same animal under 26B, Feb. 15.

$\ddagger$ Numbers refer to individual dogs, letters to individual experiments on the same dog. 
TABLE IV

Simultaneous measurements of blood volume by a carbon monoxide and by a dye (T1824) method of blood volume in an adrenalectomized dog, treated with varying amounts of DOCA and of cortical extract

\begin{tabular}{|c|c|c|c|c|c|c|c|c|}
\hline \multirow{3}{*}{ Date } & \multirow{3}{*}{$\begin{array}{c}\text { Body } \\
\text { weight }\end{array}$} & \multirow{3}{*}{ Status of treatment* } & \multirow{3}{*}{$\underset{\text { space }}{\text { SCN }}$} & \multirow{3}{*}{$\begin{array}{l}\text { Serum } \\
\text { protein }\end{array}$} & \multirow{3}{*}{$\begin{array}{l}\text { Relative } \\
\text { cell } \\
\text { volume, } \\
\text { venous }\end{array}$} & \multicolumn{2}{|c|}{ Blood volume } & \multirow{3}{*}{ Ratio 2:1 } \\
\hline & & & & & & & 2 & \\
\hline & & & & & & $\underset{\text { method }}{\text { CO }}$ & $\begin{array}{c}\text { Dye } \\
\text { method }\end{array}$ & \\
\hline 1942 & kgm. & & cc. & $\begin{array}{l}\text { grams } \\
\text { per cent }\end{array}$ & per cent & $c c$. & $c c$. & \\
\hline $\begin{array}{l}\text { May } 18 \\
28 \\
28 \\
\text { June } 3 \\
11 \text { (a.m.) } \\
11 \text { (p.m.) } \\
18 \\
18 \\
\text { July } 10 \\
16 \\
24\end{array}$ & $\begin{array}{r}9.1 \\
9.8 \\
9.6 \\
10.0 \\
10.0 \\
10.7 \\
9.4 \\
9.0 \\
9.9\end{array}$ & $\begin{array}{l}\text { Adequate treatment with a little cortin } \\
\text { Well treated with cortin and DOCA } \\
\text { Well treated with cortin and DOCA } \\
\text { Well treated with cortin alone } \\
\text { Well treated with cortin alone } \\
\text { Well treated with DOCA alone } \\
\text { Just maintained on cortin and DOCA } \\
\text { No cortin or DOCA since July } 10 \\
\text { Well treated with DOCA alone }\end{array}$ & $\begin{array}{l}2560 \\
2960 \\
\\
3120 \\
\\
3270 \\
2900 \\
2010 \\
3160\end{array}$ & $\begin{array}{l}7.54 \\
5.88 \\
5.53 \\
5.56 \\
5.94 \\
5.73 \\
6.83 \\
5.26\end{array}$ & $\begin{array}{l}51.4 \\
31.0 \\
38.5 \\
38.2 \\
32.0 \\
41.2 \\
50.4 \\
58.6 \\
29.5\end{array}$ & $\begin{array}{l}567 \\
945 \\
977 \\
824 \\
705 \\
724 \\
734 \\
636\end{array}$ & $\begin{array}{r}632 \\
713 \\
762 \\
\\
794 \\
847 \\
1112 \\
604 \\
750\end{array}$ & $\begin{array}{l}1.20 \\
1.54 \\
0.82 \\
1.18\end{array}$ \\
\hline
\end{tabular}

* DOCA means desoxycorticosterone acetate.

blood volumes than they did during studies in which treatment was more adequate. The decline was mainly at the expense of the plasma volume. Measurements of both methods therefore indicated correctly the decline in the plasma volume which almost certainly accompanies inadequate treatment (12), being much lowered when treatment was discontinued or insufficient. The technical difficulties in using carbon monoxide, mentioned in experiments with hemorrhage, are present in this study as well, and may account for some of the variability in the ratios.

\section{In hemorrhage experiments}

In Table $\mathrm{V}$ are presented the pertinent data from experiments done following repeated hemorrhages. Internal evidence, in the form of agreement between most successive determinations and between carbon monoxide and T1824 measurements, suggests that, in spite of the occasional

TABLE V

Simultaneous measurements of blood volume by a carbon monoxide method and by a dye (T1824) method in a dog subjected to repeated hemorrhages

\begin{tabular}{|c|c|c|c|c|c|c|c|c|}
\hline \multirow{3}{*}{ Date } & \multirow{3}{*}{$\begin{array}{c}\text { Body } \\
\text { weight }\end{array}$} & \multirow{3}{*}{$\begin{array}{l}\text { Amount of blood } \\
\text { lost since pre- } \\
\text { ceding study }\end{array}$} & \multirow{3}{*}{$\begin{array}{l}\text { Relative cell } \\
\text { volume, } \\
\text { venous }\end{array}$} & \multicolumn{2}{|c|}{ Cell volume } & \multicolumn{2}{|c|}{ Blood volume } & \multirow{3}{*}{ Ratio 2:1 } \\
\hline & & & & \multirow{2}{*}{ CO method } & \multirow{2}{*}{ Dye method } & 1 & 2 & \\
\hline & & & & & & CO method & Dye method & \\
\hline $\begin{array}{rr}1942 \\
\text { May } 8 \\
14 \\
29 \\
\text { June } 12 \\
17 \\
22 \\
26 \\
29 \\
3 \\
\text { July } 9 \\
13 \\
17 \\
22 \\
27 \\
3 \\
25\end{array}$ & $\begin{array}{l}\text { kgm. } \\
21.0 \\
20.6 \\
20.7 \\
21.5 \\
21.2 \\
22.2 \\
20.7 \\
20.9 \\
20.4 \\
19.9 \\
18.4 \\
19.4 \\
20.9 \\
20.5\end{array}$ & $\begin{array}{r}c c . \\
0 \\
0 \\
0 \\
0 \\
600 \\
500 \\
900 \\
300 \\
960 \\
740 \\
1285 \\
1115 \\
1335 \\
0 \\
0 \\
0\end{array}$ & $\begin{array}{c}\text { per cent } \\
36.0 \\
36.9 \\
46.4 \\
43.4 \\
38.0 \\
35.2 \\
26.1 \\
29.0 \\
24.8 \\
27.3 \\
18.9 \\
23.0 \\
15.1 \\
23.2 \\
39.4 \\
55.2\end{array}$ & $\begin{array}{r}c c . \\
732 \\
746 \\
1000 \\
990 \\
831 \\
795 \\
625 \\
693 \\
567 \\
585 \\
487 \\
556 \\
420 \\
561 \\
955 \\
1223\end{array}$ & $\begin{array}{r}c c . \\
887 \\
844 \\
1110 \\
929 \\
791 \\
722 \\
495 \\
591 \\
753 \\
486 \\
\\
437 \\
259 \\
483 \\
2230 \\
2520\end{array}$ & $\begin{array}{c}c c . \\
2030 \\
2020 \\
2150 \\
2280 \\
2185 \\
2260 \\
2395 \\
2385 \\
2285 \\
2142 \\
2580 \\
2415 \\
2780 \\
2420 \\
2420 \\
2215\end{array}$ & $\begin{array}{c}c c . \\
2460 \\
2285 \\
2395 \\
2140 \\
2080 \\
2050 \\
1895 \\
2035 \\
3035 \\
1780 \\
\\
1900 \\
1715 \\
2080 \\
5660 \\
3550\end{array}$ & $\begin{array}{l}1.21 \\
1.13 \\
1.12 \\
0.94 \\
0.95 \\
0.91 \\
0.79 \\
0.85 \\
1.33 \\
0.83 \\
0.79 \\
0.62 \\
0.86 \\
2.34 \\
1.60\end{array}$ \\
\hline
\end{tabular}


technical difficulties (see section above on Methods), most of these blood volume determinations are not unsatisfactory. Excluding the 2 final figures for blood volume by the dye method, which are manifestly incorrect, a mean blood volume of $2310 \mathrm{cc}$. is obtained by the carbon monoxide method and of $2142 \mathrm{cc}$. by the dye method, a reasonable correspondence. Of interest are certain determinations which vary widely from the above means and from each other. In one instance, the blood volume determined with carbon monoxide was $2730 \mathrm{cc}$; that by the dye, done at the same time, was $1715 \mathrm{cc}$. In another instance, the dye gave a volume of $5660 \mathrm{cc}$., a ridiculously high figure. We have no reason for believing that these aberrant values actually represent blood volume changes, nor, in the case of dye measurements, that they are due to faulty technic, because usually, in this animal and in normal animals (1), we obtained reasonable values at other times, using the same technic. In the case of the carbon monoxide measurements, since residual carbon monoxide was not measured, the high values obtained by this method could result from insufficient correction for this residuum. A leak in the carbon monoxide administering system, due to failure to seal the mask with petrolatum, may also well have played a rôle. In the case of the dye, very high and very low values can be explained only by unusual distribution or disposition of the dye. The dye did not disappear with unusual rapidity in experiments with either very low or very high plasma volumes. Had extrapolated rather than 10minute values been used in calculating blood volume by the dye method, these abnormal values for blood volume would therefore still have persisted.

\section{Simultaneous measurements after intravenous epi- nephrine}

As indicated under the section on methods, technical difficulties prevent a comparison of carbon monoxide and dye measurements before and immediately after giving epinephrine. In Table VI are summarized experiments showing the effect of epinephrine. In the majority, both of normal and of splenectomized animals, the carbon monoxide method indicates that no change of blood volume was produced by epinephrine.
TABLE VI

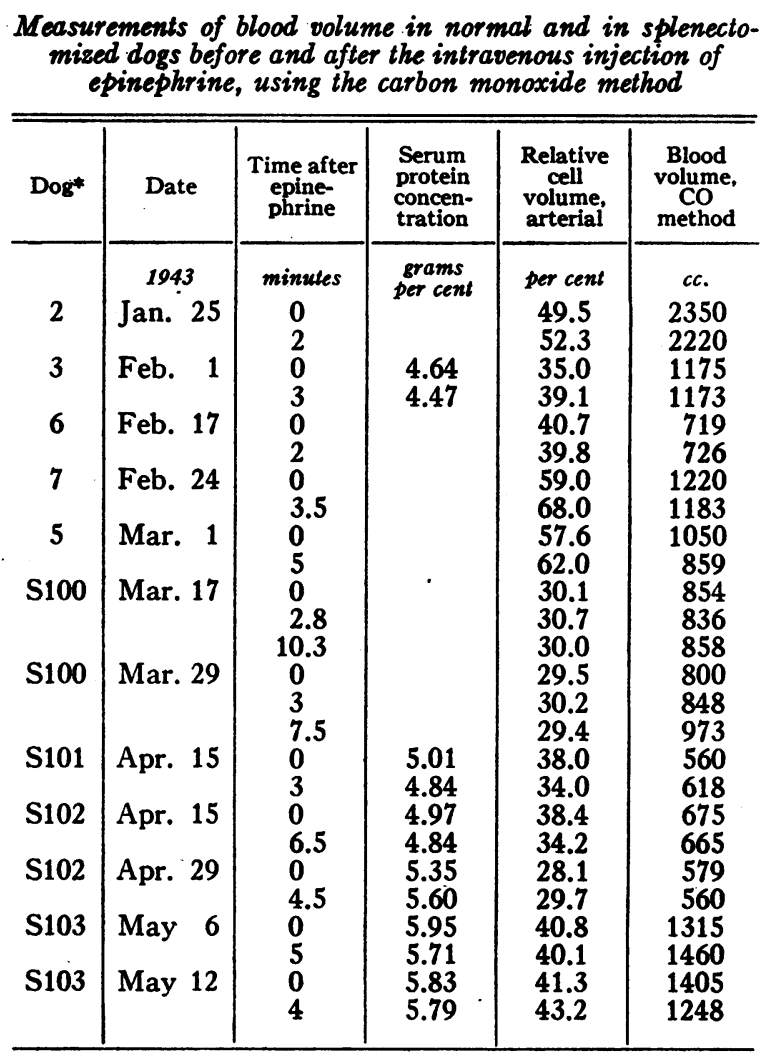

* Numbers are the same as those of Table II, "S" refers to splenectomized dogs.

At times, however, there was a small apparent increase, and at other times, an apparent decrease. Whether these apparent changes represent true changes is questionable, since they may simply result from faulty sampling of the average relative cell volume due to dynamic changes caused by epinephrine.

Comparison of the changes in plasma volume, as determined by carbon monoxide and by T1824, with those calculated from relative cell volume and from serum protein changes

In Figures 1, 2A, 2B, 2C, and 2D, are 5 correlation charts based on data in the preceding tables. Plasma volume changes by dye method and by carbon monoxide method have been calculated from the blood volume figures, and expressed in terms of percentage of initial values. Changes in plasma volume for the same experiment have been calculated from changes in concentration of serum protein and of relative cell volume, accord- 
ing to the procedures outlined under Methods. If the 2 methods compared give the same results, points will fall along the diagonal axis; conversely, the distance of points from the axis measures the discrepancy between the results by the 2 methods. Points falling in the upper left or lower right-hand quadrants indicate an inverse correlation.

Plasma volume changes by the monoxide and dye methods are fairly well correlated in a qualitative sense (Figure 1). There are 3 points lying on the abscissa, 2 of them corresponding to those experiments with acute salt depletion in which the monoxide indicated a decline in blood volume but the dye did not. With these exceptions, both methods regularly indicated a change in the same direction. Quantitatively, the correlation is not satisfactory, since points are widely scattered on both sides of the diagonal line. More points are above than below the diagonal, indicating that in a majority of cases the dye method indicated less of a change than did the monoxide method.

Changes in plasma volume as measured by change in plasma protein concentration are compared with simultaneous measurements of change in plasma volume by the dye and monoxide

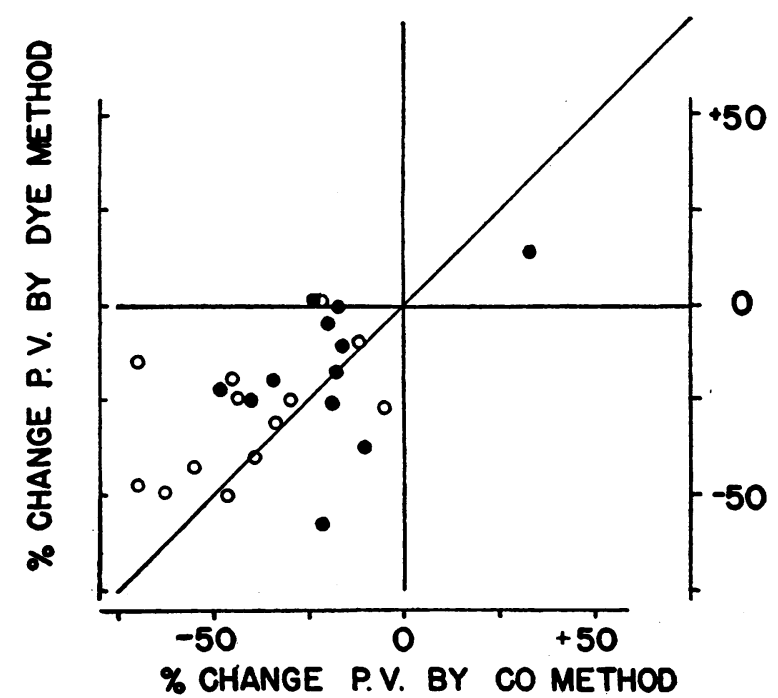

Fig. 1. Relative Plasma Volume. Individual Simultaneous Measurements of Change in Plasma Volume by the Dye Method and by the Carbon MonOXIDE METHOD

Solid circles indicate experiments of Table III; open circles all other experiments. methods in Figure 2A and 2B. Although there is some correlation, the large number of points in the upper left-hand quadrant corresponds to experiments in which the serum protein method indicates an increased plasma volume while the other methods indicate a decreased volume. Since these all occurred in experiments in which a decrease might be expected on physiological grounds, the validity of the serum protein method in these cases must be doubted.

Even more marked is the frequency with which the correlation is inverted between changes measured by the hematocrit method and those measured by the dye and monoxide methods, Figure $2 \mathrm{C}$ and $2 \mathrm{D}$. Some of the aberrant points in the upper left-hand corner are derived from experiments with changes in salt concentration of body fluids, which might be expected to affect the validity of the hematocrit method, but others are derived from simple shock experiments in which no such concentration changes occurred.

\section{DISCUSSION}

The conclusion was reached in a previous paper (1) that neither the dye method nor the carbon monoxide method regularly measures absolute blood volume in normal subjects. The experience with pathological subjects tends to confirm and extend this conclusion. In pathological as in normal states, either method may on occasion give the larger value, and it is not possible to assert that either one consistently measures absolute blood volume. There is more tendency in pathological than in normal subjects for the dye measurement to exceed that by monoxide. This tendency toward a larger value for the blood volume in many of the patients may be associated with their particular disease, or it may be due to some non-specific factor common to this pathological group as a whole. For example, the patients had all been confined to bed for some days prior to the determination of blood volume, while the normal subjects had previously been ambulatory. No such explanation seems possible of the frequent high values given by the dye methods in shocked animals. It is possible, however, that the high values in shock resulted from the accelerated rate with which dye escapes from the vascular space in this condition. The valid- 

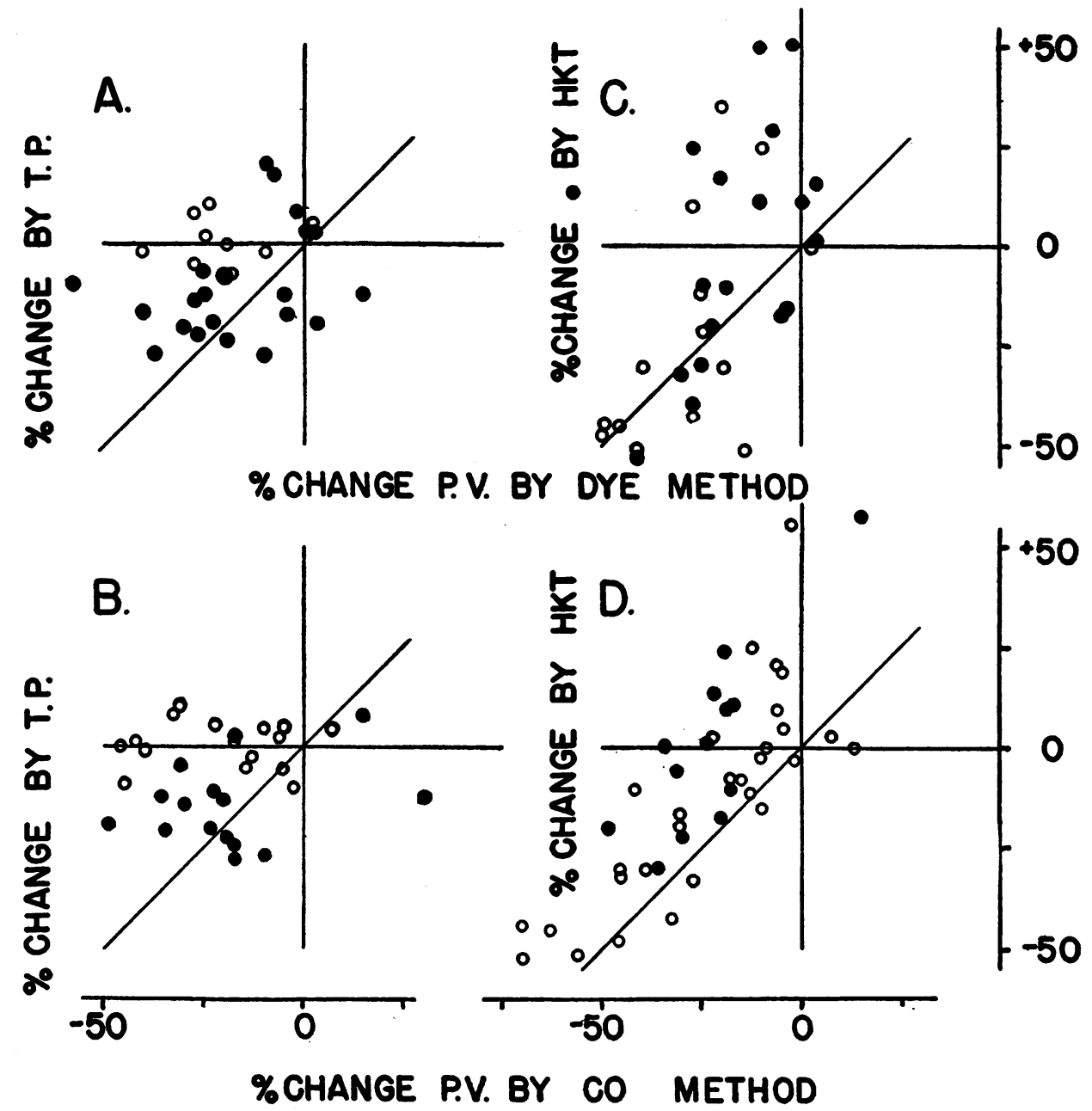

Fig. 2. Relative Plasma Volume. Individual Simultaneous Measurements of Change in Plasma Volume by 4 Different Methods

In A and B, relative plasma volumes calculated from change in total protein (T.P.) concentration in serum are compared with relative plasma volumes measured by the dye method and by the carbon monoxide method, respectively. In C and D, relative plasma volumes calculated from change in the fraction of cells in whole blood (Hkt) are compared with relative plasma volume measured by the dye method and by the carbon monoxide method, respectively. Solid circles indicate experiments of Table III; open circles all other experiments.

ity of the dye method in shock will be discussed more fully later.

On the whole, it seems probable that both methods tend to exaggerate the true blood volume. In previous papers $(1,2)$, it has been shown that most of the technical errors in the measurement of blood volume by the monoxide method tend to result in values exceeding the actual volume. Some of the reasons which are commonly supposed to support this conclusion are not, however, entirely valid. Thus, it has been suggested that carbon monoxide measures a space larger than the vascular space because some carbon monoxide leaves the intravascular space and combines with the myoglobin of muscle and with the blood pigments in reservoirs such as the spleen and bone marrow. That the loss of carbon monoxide to myoglobin is not responsible for an appreciable error is supported by the finding, repeatedly confirmed by ourselves and by others $(13,14)$, that the concentration of carbon monoxide in the blood is quite constant 
a few minutes after the inhalation of the gas. Even strenuous exercise, which greatly increases the flow of blood through the muscles and so might be expected to facilitate a loss of carbon monoxide to them, does not appreciably affect the carbon monoxide concentration of the blood $(13,14)$. The slight drop in concentration of carbon monoxide in the blood, observed by Asmussen within the first few minutes of giving carbon monoxide and attributed by him to loss of carbon monoxide to the pigment stores, can just as well be explained by the process of distribution within the vascular space.

There is also much evidence that carbon monoxide is not actively taken up by the red blood cells of the spleen (15). In animals, direct analysis of the spleen showed that carbon monoxide tended to be excluded unless the blood was more than 20 per cent saturated, a saturation rarely attained with the amounts of carbon monoxide used by us or by others in blood volume measurements. Even with high blood concentrations, it took several hours for the same concentration to be reached in the spleen. Our own demonstration that carbon monoxide measures the same volume in splenectomized as in normal dogs likewise indicates that carbon monoxide is not lost to the spleen.

A loss of carbon monoxide to the pigment stores, particularly to those of the bone marrow, is not excluded by our work. Such a loss was in fact postulated by Whipple and his associates (16), Barcroft and his associates (17), and others. In any event, any losses due to escape of carbon monoxide from the intravascular space would tend to produce misleadingly high results. In so far as dye volumes equal or exceed those of carbon monoxide, the dye method must therefore also give too high a value. It does not seem probable, however, that the loss of carbon monoxide to the bone marrow is very great, for the considerations relating to the fixation of carbon monoxide by myohematin are also valid here $(13,14)$.

There are various reasons for believing that the dye method also regularly gives excessive values for the plasma volume. The validity of this method depends on the assumption that either a negligible amount of dye is lost during mixing time, or that, if the initial concentration is derived by extrapolation from the curve representing the rate of dye disappearance, the dye leaves the circulation at a uniform rate at all times after its injection. Both of these assumptions are open to serious question. Since the dyes used in this method are attached to the protein of plasma $(18,19)$, it is probably this attachment which prevents the rapid loss of dye from the vascular space. It is therefore possible that some loss of free dye from the circulation may take place immediately after injection, before attachment has had time to develop. The quantitative importance of this factor is unknown, but in so far as it occurs, plasma volume measurements will be exaggerated. More definite is the rapid loss of dye into the lymphatic system $(20,21,22)$, which necessarily means that the apparent volume of distribution of the dye, calculated by the usual extrapolation method, must include some of the lymphatic space along with the intravascular space. There is also evidence that the liver may act as a temporary repository for the dye $(23,24,25)$. It is not known whether the appearance of the dye T1824 in the tubular epithelium of the kidney (26) occurs rapidly enough to affect the early distribution of the dye, or whether the decolorization of the dye with time occurs in vivo as it does in vitro (27), but these factors, if present, would further accentuate the exaggeration of the plasma volume by the dye method.

Whipple and his associates (28) still maintain that plasma and cells are not evenly distributed throughout the circulation. The evidence cited in favor of this contention is, however, open to other interpretation. They originally advanced the hypothesis of an uneven distribution in order to explain the smaller values for blood volume obtained with the monoxide method when compared with those obtained with the brilliant vital red dye method. However, upon observing that some dye was lost to the lymphatics, Smith (20) conceded that this might account in part for the greater space measured by the dye than by carbon monoxide. Waterfield (29) has contributed evidence to support this view in the form of experiments in which it was shown that increases in leg volume corresponded to blood volume changes which occurred in changing from the recumbent to the standing position. The 
recent study by Stead and Ebert (30), supporting the view that relative cell volume measurements by hematocrit do not reflect the relationship of cells to plasma throughout the body, depends for the validity of its argument on the unwarranted assumption that the dye method measures actual plasma volume. There are, on the other hand, studies such as those of Steinmann (31), in which exactly the same hemoglobin concentration was found in blood taken simultaneously from ear, finger, toe, arm vein, and mesenteric veins; in normal circulatory states the concentration did not vary by more than one part in a hundred.

Our own observations indicate that relative cell volumes of arterial blood and of venous blood are identical except under conditions of profound shock. In shock, it is certainly true that the distribution of cells throughout the vascular system may be uneven, and this factor must be taken into account in comparing dye and monox ${ }^{\star}$ ide measurements under these conditions. If the measured relative cell volume is higher than the true average relative cell volume, blood volume by the dye method will be too high and that by the monoxide method too low; conversely, if the measured value is less than the average, the distortion by each method will be reversed. In our shock experiments, arterial blood was used; if there was any difference between the relative cell volume in arterial and venous blood, it was always higher in the latter. In other words, if arterial blood were not a fair sample of average blood, it differed by having less than the average proportion of cells; this is reasonable also from what is known of the distribution of blood in shock. This error in sampling would therefore tend to make dye measurements too low and monoxide measurements too high; it cannot therefore be responsible for the fact that dye measurements in shock usually exceed those by monoxide.

In our bleeding experiments, the total cell mass, as determined by the carbon monoxide method, bears an approximately linear relationship to the relative cell volume as measured by the hematocrit. Just such a relationship was observed by Hahn and Bale (32) when radioactive cells were used to measure total cell mass. With the exception of certain of the aberrant studies previously alluded to, the cell mass as determined by the dye, T1824, likewise bears a linear relationship to the hematocrit. Hahn, using brilliant vital red and a modification of the procedure used by Whipple, obtained no such relationship (33). This suggests that brilliant vital red as used by these investigators does not measure a space equivalent to that measured by T1824 with the Gibson and Evelyn technic. The correlation of changes in cell mass, as measured by both the carbon monoxide and dye technics, with changes in relative cell volume lends support to the idea that the ratio of cells to plasma is normally the same throughout the circulation.

Certain observations in the course of our experiments indicate that repeated use of the blue dye may lead to anomalous results. In the experiment with repeated bleedings (Table V), dye injections were given many times. Ultimately, sporadic increases of plasma volume as measured by the dye method appeared, much too large to indicate real changes in plasma volume. Lindhard (34) has observed successively larger values for blood volume with prolonged repeated use of the dye, vital red. Thompson and his associates (35), on the other hand, have reported smaller apparent plasma volumes with repeated injections of dye, an observation contrary to that of Lindhard. The explanation of these curious results is at present obscure.

There is much evidence that both methods, although of doubtful value in the measurement of.absolute blood volume, may be usefully applied to the detection of changes in blood and plasma volume. The correlation in Figure 1A indicates that reductions in plasma volume are recorded with considerable regularity by both methods, although the extent of the recorded change is not usually the same with the 2 methods. There is a tendency for the dye method to indicate less of a reduction than does the monoxide method. This is especially true under conditions of shock, and may, in a few instances, lead to recording of a reduction by the monoxide but not by the dye method. The increased rate of dye loss in shock (36) undoubtedly tends to exaggerate the plasma volume by the dye method in shock as compared with the normal status. It seems reasonable, therefore, to doubt 
the dye rather than the monoxide method under these circumstances.

It is not just, however, to assign all the quantitative change by the 2 methods to vagaries in the dye method alone. In quite a number of cases, the dye method indicates more of a reduction than does the monoxide, a difference which obviously cannot be explained by abnormally rapid loss of dye. There is really no reason to believe that the monoxide method measures relative plasma volume more exactly than does the dye. It is fairly clear that both methods are fairly reliable qualitative, but not quantitative, measures of relative plasma volume. In this respect, they are clearly superior to methods based on changes in serum protein concentration or on changes in relative cell volume. Indeed, although these older methods based on protein and hematocrit measurements are still widely employed in clinical and experimental work (37), they may frequently be seriously misleading, even in a qualitative sense. Failure of the dye method to indicate a reduction of plasma volume in shock does not prove that such a decrease has not taken place. On the other hand, demonstration of a reduction in plasma volume in shock by either dye or monoxide is good evidence that a change actually did take place in the direction indicated.

\section{CONCLUSIONS}

1. The relationship between simultaneous measurements of blood volume with the dye, $\mathrm{T} 1824$, and with carbon monoxide is more variable in abnormal than in normal subjects.

2. In some abnormal subjects, the dye method tends to give considerably higher values than does the monoxide method. This is especially apt to occur in dogs in secondary shock.

3. It is probable that both methods tend to give absolute values which exceed the true blood volume.

4. Both methods consistently indicate correctly the direction of change in plasma volume. They are therefore useful relative measures of plasma volume, at least in a qualitative sense.

5. The only exception occurs in some cases of traumatic shock, in which the dye method may fail to record a decline in plasma volume.
6. On the other hand, an indication by the dye method that there has been a decline of plasma volume in shock almost certainly means that such a decline has taken place. The dye method can therefore be used in the study of plasma volume in shock, provided these limitations be taken into account in interpreting the results.

7. Dye and monoxide methods both indicate changes in plasma volume more reliably than do changes in serum protein concentration or in relative cell volume, which may, in fact, wrongly indicate even the direction of change.

The authors are indebted to Professor John Fulton who generously placed the facilities of the Laboratory of Physiology of the Yale University School of Medicine at their disposal.

\section{BIBLIOGRAPHY}

1. Hopper, J., Jr., Tabor, H., and Winkler, A. W., Simultaneous measurements of blood volume in man and dog by means of Evans blue dye, T1824, and by means of carbon monoxide. I. Normal subjects. J. Clin. Invest., 1944, 23, 628.

2. Hopper, J., Jr., and Tabor, H., Adaptation of the palladium method for the determination of carbon monoxide to the calculation of blood volume. To be published.

3. Peters, J. P., and Van Slyke, D. D., Quantitative Clinical Chemistry. Volume II. Methods. Williams and Wilkins Co., Baltimore, 1932.

4. Hahn, P. F., Bale, W. F., and Bonner, J. F., Jr., Removal of red cells from the active circulation by sodium pentobarbital. Am. J. Physiol., 1943, 138, 415.

5. Jarcho, L. W., The effect of nembutal-ether anesthesia upon blood concentration. Am. J. Physiol., 1943, 138, 458.

6. Darrow, D. C., and Yannet, H., Metabolic studies of the changes in body electrolyte and distribution of body water induced experimentally by deficit of extracellular electrolyte. J. Clin. Invest., 1936, $15,419$.

7. Elkinton, J. R., and Taffel, M., The apparent volume of distribution of sulfocyanate and of sulfanilamide in the dog. Am. J. Physiol., 1942, 138, 126.

8. Swingle, W. W., Remington, J. W., Kleinberg, W., Drill, V. A., and Eversole, W. J., An experimental study of the tourniquet as a method for inducing circulatory failure in the dog. Am. J. Physiol., 1942, 138, 156.

9. Nadal, J. W., Pedersen, S., and Maddock, W. G., A comparison between dehydration from salt loss and from water deprivation. J. Clin. Invest., 1941, 20, 691.

10. Elkinton, J. R., and Taffel, M., Prolonged water deprivation in the dog. J. Clin. Invest., 1942, 21, 787. 
11. Winkler, A. W., Elkinton, J. R., Hopper, J., Jr., and Hoff, H. E., Experimental hypertonicity: alterations in the distribution of body water, and the cause of death. J. Clin. Invest., 1944, 23, 103.

12. Britton, S. W., Adrenal insufficiency and related considerations. Physiol. Rev., 1930, 10, 617.

13. Chang, H. C., and Harrop, G. A., Jr., The determination of the circulating blood volume with carbon monoxide. J. Clin. Invest., 1928, 5, 393.

14. Asmussen, E., Determination of blood volume by the carbon monoxide method. Acta Physiol. Scandinav., 1942, 3, 156.

15. Barcroft, J., Recent knowledge of the spleen. Lancet, $1925,1,319$.

16. Arnold, H. R., Carrier, E. B., Smith, H. P., and Whipple, G. H., Blood volume studies. V. The carbon monoxide method-its accuracy and limitations. Am. J. Physiol., 1921, 56, 313.

17. Barcroft, J., Binger, C. A., Bock, A. V., Doggart, J. H., Forbes, H. S., Harrop, G., Meakins, J. C., and Redfield, A. C., Observations upon the effect of high altitude on the physiological processes of the human body carried out in the Peruvian Andes, chiefly at Cerro Pasco. Phil. Trans. of the Royal Soc. of London, 1921-23, (Series B) 211, 351.

18. Rawson, R. A., The binding of T-1824 and structurally related diazo dyes by the plasma proteins. Am. J. Physiol., 1943, 138, 708.

19. Gregersen, M. I., and Rawson, R. A., The disappearance of T-1824 and structurally related dyes from the blood stream. Am. J. Physiol., 1943, 138, 698.

20. Smith, H. P., The fate of an intravenously injected dye (brilliant vital red) with special reference to its use in blood volume determinations. Bull. Johns Hopkins Hosp., 1925, 36, 325.

21. Harris, D. T., The value of the vital red method as a clinical means for the estimation of the volume of the blood. Brit. J. Exper. Path., 1920, 1, 142.

22. Ferrebee, J. W., Leigh, O. C., and Berliner, R. W., Passage of the blue dye T-1824 from the blood stream into the lymph. Proc. Soc. Exper. Biol. and Med., 1941, 46, 549.

23. McCarrell, J. D., Thayer, S., and Drinker, C. K., The lymph drainage of the gall bladder together with observations on the composition of liver lymph. Am. J. Physiol., 1941, 133, 79.

24. Peters, J. P., Serum protein in health and disease. J. Mt. Sinai Hosp., 1942, 9, 127.

25. Glider, H., Müller, O. H., and Phillips, R. A., Mixing time of T-1824 in the blood. Am. J. Physiol., $1940,129,362 \mathrm{P}$.

26. Hopper, J., Jr., and Winkler, A. W., Unpublished studies.

27. Phillips, R. A., A method for the determination of the blue dye T-1824 in plasma. J. Exper. Med., 1943, 77, 421.

28. Hahn, P. F., Ross, J. F., Bale, W. F., Balfour, W. M., and Whipple, G. H., Red cell and plasma volumes (circulating and total) as determined by radio iron and by dye. J. Exper. Med., 1942, 75, 221.

29. Waterfield, R. L., The effects of posture on the circulating blood volume. J. Physiol., 1931, 72, 110.

30. Stead, E. A. Jr., and Ebert, R. V., Relationship of the plasma volume and the cell plasma ratio to the total red cell volume. Am. J. Physiol., 1941, 132, 411.

31. Steinmann, B., Über die Bestimmung der Zirkulierenden Blutmenge beim Menschen. Arch. exper. Path. u. Pharm., 1938-39, 191, 237.

32. Hahn, P. F., and Bale, W. F., Linear relationship between the circulating red cell mass and the venous hematocrit as determined with radioactive iron. Am. J. Physiol., 1942, 136, 314.

33. Hahn, P. F., and Whipple, G. H., II. Iron metabolism. Its absorption, storage and utilization in experimental anemia. Am. J. M. Sc., 1936, 191, 24.

34. Lindhard, J., A dye-method for determining the blood volume in man. Am. J. Physiol., 1926, 77, 669.

35. Thompson, W. O., Thompson, P. K., and Dailey, M. E., The effect of posture upon the composition and volume of the blood in man. J. Clin. Invest., 1928, $5,573$.

36. Freeman, N. E., Freedman, H., and Miller, C. C., The production of shock by the prolonged continuous injection of adrenalin in unanesthetized dogs. Am. J. Physiol., 1941, 131, 545.

37. Elkinton, J. R., Gilmour, M. T., and Wolff, W. A., The control of water and electrolyte balance in surgical patients. Ann. Surg., 1939, 110, 1050. 